\title{
ПАМЯТИ УЧИТЕЛЯ
}

\section{(C) 2018 г. А.А. Горячев}

В статье освещены основные жизненные и творческие вехи известного археолога - Алексея Николаевича Марьяшева, покинувшего этот мир в марте 2018 г. Несмотря на возраст и тяжелую болезнь, А.Н. Марьяшев продолжал выезжать в экспедиции, совершать восхождения, делать новые открытия в изучении наскального искусства.

Ключевые слова: археология, А.Н. Марьяшев, петроглифы, восхождения, экспедиции, ученики, горы, альпинизм

12 марта 2018 года казахстанская наука и спорт понесли невосполнимую потерю - ушел из жизни Алексей Николаевич Марьяшев - один из первых альпинистов Казахстана, доктор исторических наук, главный научный сотрудник Института археологии им. А.Х. Маргулана. Несмотря на тяжелую болезнь и солидный возраст, он не собирался на покой. За полгода до смерти он совершил свое последнее открытие - обнаружил группу петроглифов в Хантау; за три недели до этой даты - в возрасте 84 лет совершил свое последнее восхождение; за три дня - подробно обсудил планы исследований по Хантаускому проекту и наметил экспедиции, в которых примет непосредственное участие. Но его внезапно не стало...

Алексей Николаевич Марьяшев родился 4 декабря 1933 года в г. Алма-Ате. Его воспоминания о детстве, прошедшем в трудные послевоенные годы, были наполнены юмором сквозь дымку легкой грусти. Голодное послевоенное детство, работа матери врачом в местах заключения для выживания за бесплатный паек семье; юность, полная романтики покорения горных вершин Заилийского Алатау, многие из которых в 1951-1953 гг. взяты впервые вместе с друзьями (Кайрактас, Карнизная, Восходитель, Кошка, Дальний, Октябрь, Жастар, Узловая, Первомайский), на другие проложены новые маршруты. Все это найдет отражение в его рассказах и воспоминаниях. Как и то, что позже председатель федерации альпинизма М.Э. Грудзинский по сведениям, сообщенным Алексеем Николаевичем, составил схему вершин Каргалинки и Аксая, а в 1961 г. после полета Ю. Гагарина поручил назвать его именем новую вершину. А.Н. Марьяшев с другом С. Кудериным предложили назвать именем Гагарина вновь покоренный ими один из пиков центральной части Каргалинской подковы, и с тех пор он носит имя первого космонавта. Любовь к горам Алексей Николаевич пронес через всю свою жизнь, побывав в различных уголках Зем- 


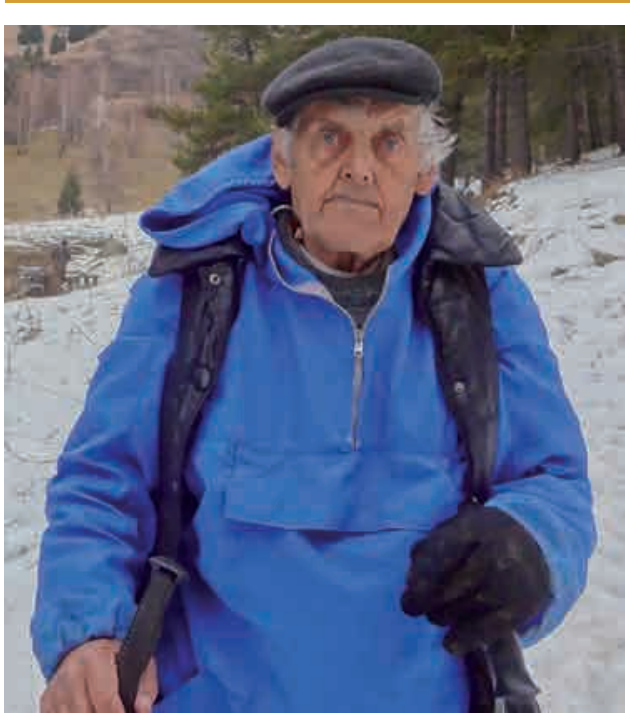

Марьямев Алексей Николаевич (1933-2018)

Alexey N. Maryashev (1933-2018)

ного шара. В память о легендарном альпинисте один из пиков (4000 м) в Карагалинском хребте, между вершинами Октябрь и Каргалинский, назван именем А.Н. Марьяшева.

В 1957 году А.Н. Марьяшев окончил историко-филологический факультет Казахского государственного педагогического института [ныне - Казахский национальный педагогический университет имени Абая - прим. авт.]. В 1957-1971 гг. Алексей Николаевич преподавал историю, русский язык и литературу, первый учебный год в школе села Кугалы Талды-Курганской [ныне Алматинской - прим. авт.] области, затем - в школах Алма-Аты. Беспокойное творческое начало, однако, взяло верх и с 1961 г. А.Н. Марьяшев стал совмещать учительский труд с работой тренера по альпинизму в вузах и спортивных клубах, а в 1971 г. окончательно расстался со школой и ограничился тренерской работой в спортивном клубе Алма-Атинского домостроительного комбината.
Благодаря альпинизму, произошла встреча Алексея Николаевича с наскальными рисунками. Интерес к ним, годы учения и становления привели в археологию. Обнаруживая многочисленные петроглифы в разных местах Тянь-Шаня и Семиречья, он все более интересовался памятниками наскального искусства, а с 1968 г. всерьез занялся их фиксацией и изучением. В 1970 г. в журнале «Природа» вышла его первая публикация «Петроглифы Иссык-Куля», а в 1971 г. в «Вестнике Академии наук КазССР»- статья «Древние наскальные рисунки Чулакских гор».

В 1970-е гг. в составе археологической экспедиции под руководством Мира Касымовича Кадырбаева А.Н. Марьяшев начинает свою научную карьеру с изучения памятников древнего наскального искусства хребта Каратау. Результатом явилась совместная научная работа, в которой были предложены методы и систематика датировки наскальных рисунков древнего Казахстана, получившая признание в отечественной науке.

В эти же годы в составе археологической экспедиции Института «Казпроектреставрация» А.Н. Марьяшев руководит раскопками цитадели городища Туркестан, ныне реконструированной и входящей в комплекс музейного комплекса мавзолея Ходжа Ахмета Ясави. В 1975-1978 гг. проводит обследование, систематизацию и учет древних петроглифов урочища Тамгалы. В серии научных статей, а позднее и в монографической работе вместе с А.Г. Максимовой и А.С. Ермолаевой, доказывает высокую научную и культурную значимость памятника.

Тогда же в Новосибирске состоялась успешная защита А.Н. Марь- 
яшевым кандидатской диссертации по теме: «Наскальные изображения Южного Казахстана». Выдающимся достижением в отечественной археологии является открытие А.Н. Марьяшевым в 1981 г. археологического комплекса памятников долины реки Коксу в районе хребта Ешкиолмес. Наиболее значительным материалом археологического комплекса Ешкиолмес являются петроглифы. Это самое крупное скопление петроглифов в Казахстане (свыше 15 тыс.), которое представляет яркое и самобытное искусство местного населения от эпохи бронзы до средневековья. Его изучение позволило А.Н. Марьяшеву разработать основные принципы периодизации и хронологии наскальных изображений Южного Казахстана и Семиречья, ввести петроглифы в качестве источника знаний по истории и культуре древних племён Казахстана. В 1995 году в Сибирском отделении РАН он защитил докторскую диссертацию «Наскальные изображения Средней Азии, Южного Казахстана и Семиречья. Вопросы хронологии, ин- терпретации и эволюции наскального искусства». Изучению петроглифов Казахстана и Средней Азии Алексей Николаевич посвятил все 40 лет своей научной жизни.

С 1981 по 1991 гг. Алексей Николаевич Марьяшев преподавал древнюю историю и археологию в Казахском педагогическом институте им. Абая. Перейдя на работу в Институт археологии им. А.Х. Маргулана, он продолжает читать лекции в различных вузах. А затем длительное время (1990-2000 гг.) преподает и ведет практические семинары по краеведению и туризму в университете «Туран», за которые он удостаивается профессорского звания.

Через его руки прошли десятки молодых талантливых ребят, которые после встречи с ним избрали историческую науку и археологию своей профессией. Многие начинающие специалисты, даже не учившиеся у А.Н. Марьяшева, считают его своим наставником. Большинство своих публикаций он писал в соавторстве с ними, щедро делясь опытом. Алек-

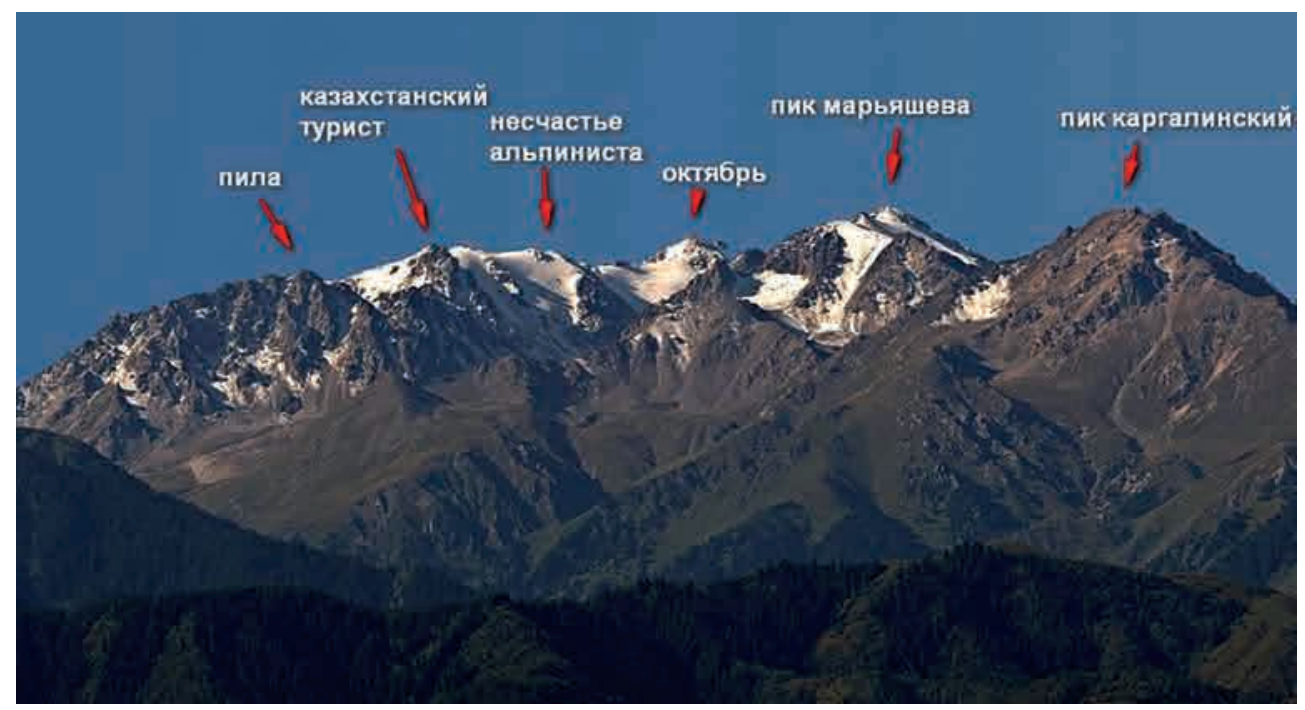

Пик Марьяшева

Maryashev peak 
сей Николаевич стремился сразу после полевого сезона опубликовывать материалы, привлекая и обучая молодежь видеть и понимать результаты исследований.

В 1980-1990-е гг. помимо работ над проблемами петроглифоведения Центральной Азии (исследования памятников наскального искусства хребтов Каратау и Тарбагатай, региона Семиречья и Восточного Казахстана, Центрально- и Северо-ТяньШаньских гор), А.Н. Марьяшев активно занимался изучением памятников эпохи бронзы Семиречья. Под его руководством были открыты первые древние поселения региона (Талапты и Куйган), исследованы погребальнопоминальные традиции андроновских племен Семиречья. Одним из главных открытий А.Н. Марьяшева является выделение своеобразных погребальных памятников эпохи бронзы кульсайского типа в высогорной зоне Заилийского и Кунгей Алатау.

В 1990-2000-е годы А.Н. Марьяшев руководил исследованиями целой серии международных экспедиций, в том числе и по проекту INTAS (1999-2001). В результате этих работ впервые были проведены социальноэкономические реконструкции развития древних племен эпохи бронзы Семиречья в отдельных микрорегионах (Тургень-Асы, Серектас, Баянжурек). Результаты научных изысканий по проекту позволили поднять изучение древних культур эпохи бронзы южных регионов Казахстана на новый международный уровень решения исследовательских задач.

Среди отечественных научных программ наиболее масштабными были исследования по программе «Культурное наследие» по проектам «Свод памятников истории и куль-

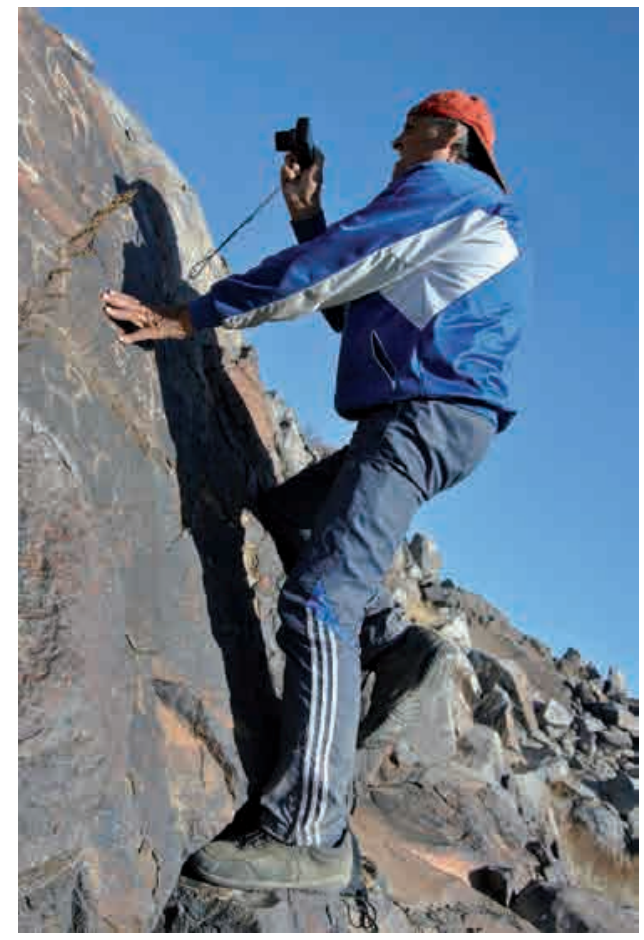

А.Н. Марьямев за фиксаичей петроглифов в возрасте чуть старше 75 Maryashev A.N. for fixing petroglyphs aged slightly over 75

туры Алматинской области» (20042008) и «Памятники наскального искусства Южного Казахстана и Жетысу». Совместно с коллегами и учениками Ю.А. Мотовым, А.А. Горячевым, С.А. Потаповым по Своду было обследовано свыше 2500 памятников истории, археологии и архитектуры. Открыты целые серии памятников наскального искусства, древних поселений и могильников. В Жетысу на сегодняшний день известно свыше 100 археологических комплексов бронзового века.

Рассматривая петроглифические скопления как святилища - «храмы под открытым небом», А.Н. Марьяшев уделял большое внимание раскрытию семантики их мотивов и образов. Он связывал наскальное искусство с мифо-ритуальными пред- 
ставлениями их создателей. Впервые обратил внимание на особую архитектонику археологических комплексов близ древних петроглифов. Эти исследования дали ему возможность значительно пополнить представления об эволюции наскального искусства от эпохи бронзы до средневековья и этнографического времени.

Алексей Николаевич Марьяшев - автор свыше 30 монографий и более 70 статей по самым различным проблемным вопросам древней и средневековой истории и археологии Казахстана и Центральной Азии. Неустанный исследователь, первооткрыватель, романтик, «презревший грошовый уют»...

Светлая память и огромная благодарность большому Ученому и Учителю останется в наших сердцах навсегда!

\section{Список основных публикаций А.Н. Марьяшева}

Монографии:

Наскальные изображения хребта Каратау. Алма-Ата: Наука, 1977. 232 с. (в соавт. с Кадырбаевым М.К.).

Наскальные изображения урочища Тамгалы. Алма-Ата: Онер, 1985. 144 с. (в соавт. с Максимовой А.Г., Ермолаевой А.С.).

Наскальные изображения в горах Ешки-Ольмес. Алма-Ата: Гылым, 1991. 80 с. (в соавт. с Рогожинским А.Е.).

Наскальные изображения Саймалы-Таша. Алма-Ата: КазНИИНКИ, 1992. 110 с. (в соавт. с Мартыновым А.И., Абетековым А.К.).

Felsbilderim Siebenstromland // Repertoire des petroglyphesd' Asie Centrale. Paris, 1998. 146 c. (в coasm. c Goryachev A.A., Potapov S.A.).

Наскальные изображения Семиречья. Алматы: Фонд «ХXI век», 2002. Изд. 2-е. 264 с. (в соавт. с Горячевым А.А.).

Наскальные изображения в горах Ешкиольмес. Алматы: Фонд «ХХІ век», 2005. 226 с. (в соавт. с Байпаковым К.М., Горячевым А.А., Потаповым С.А.).

Новые петроглифы Каратау. Алматы: Институт археологии им. А.Х. Маргулана; «Кумбез», 2007. 128 с. (в соавт. с Байтанаевым Б.А., Байпаковым К.М.).

Петроглифы Баян-Журека. Алматы: Институт археологии им. А.Х. Маргулана, 2008. 200 с. (в соавт. с Байпаковым К.М.).

Петроглифы Малого Каратау и западной оконечности Киргизского Алатау. Алматы: «Археологическая экспертиза», 2013. 120 с. (в соавт. с Байпаковым К.М.).

Древности Кулжабасы. Алматы: Институт археологии им. А.Х. Маргулана, 2013. 150 с. (в соавт. с Железняковым Б.А.).

Петроглифы раннего железного века Жетысу. Алматы: Институт археологии им. А.Х. Маргулана, 2014. 204 с. (в соавт. с Бейсеновым А.3.).

Статьи и публикации:

Древние наскальные рисунки Чулакских гор // Вестник АН КазССР. 1971. № 9. С. 65-69.

Каратауские колесницы // Археологические исследования в Казахстане. Алма-Ата: Наука, 1973. С. 128-145 (в соавт. с Кадырбаевым М.К.).

Новые петроглифы урочища Тамгалы // Вестник АН КазССР. 1979. № 8. С. 50-54 (в соавт. с Ермолаевой А.С., Мотовым Ю.А.).

«Звериный» стиль в петроглифах Казахстана (опыт классификации) // Скифосибирский мир. Искусство и идеология. Новосибирск: Наука, 1987. С. 121-123 (в соавт. с Рогожинским А.Е.).

Культовые сюжеты в петроглифах эпохи энеолита и бронзы // Маргулановские чтения1990: материалы конференции. М.: Институт археологии им. А.Х. Маргулана, 1992. С. 212-222 (в соавт. с Потаповым С.А.). 
Вопросы периодизации и хронологии памятников эпохи бронзы Семиречья // PA. 1993. № 1. С. 5-19 (в соавт. с Горячевым А.А.).

Памятники кульсайского типа в горной зоне Семиречья // История и археология Семиречья. Алматы: Институт археологии им. А.Х. Маргулана, 1999. С. $44-56$ (в соавт. с Горячевым А.А.).

Long Term Occupation and Seasonal Settlement of Eastern Eurasian Pastoralist sat Begash, Kazakhstan // Journal of Field Archaeology. 2006. 32 (3), 221-242 (в coaвm. c Frachetti M.D.).

Петроглифы поздней бронзы и раннего железного века в урочище Ой-Джайляу // Известия НАН РК. Сер. обществ. наук. 2008. С. 101-109 (в соавт. с Горячевым А.А.).

Итоги изучения памятников эпохи бронзы Жетысу // Свидетели тысячелетий: археологическая наука Казахстана за 20 лет (1991-2011): сб. научн. статей, посвящ. 20-летию Независимости Республики Казахстан. Алматы: Институт археологии им. А.Х. Маргулана, 2011. С. 313-337 (в соавт. с Горячевым А.А.).

New discoveries at Kulzhabasy in Kazakhstan (Otar, Djambul Oblys) // INORA. 2013. № 65, 1-6 (в coaвm. c Hermann L., Zheleznyakov B.).

Поселения горной части Семиречья и вопросы экологии и хозяйства в бронзовом веке // Известия НАН РК. Сер. обществ. и гум. наук. 2014. № 5 (297). С. 15-22 (в соавт. с Фрачетти М.Д., Доумани П.Н.).

Древние поселения и могильники хребта Ешкиольмес // История и археология Семиречья. Алматы: Институт археологии им. А.Х. Маргулана, 2017. Вып. 5. С. 91-111 (в соавт. с Горячевым А.А., Потаповым С.А.).

\section{Сведения об авторе:}

Горячев Александр Анатольевич - старший научный сотрудник, Институт археологии им. А.Х. Маргулана (г. Алматы, Казахстан); aga.2805@mail.ru

\section{ҰСТАЗДЫ ЕСКЕ АЛУ}

\section{А.А. Горячев}

Мақалада 2018 жылы наурызда өмірден озған танымал археолог - Алексей Николаевич Марьяшевтің өмірі мен мұрасының негізгі кезеңі қарастырылады. Өзінің егде тартқан жасы мен денсаулығына қарамастан А.Н. Марьяшев экспецияларға шығуды, биіктерге шығу мен тасқа жазылған өнердегі жаңа ашуларын жалғастырып келді.

Түйін сөздер: археология, А.Н. Марьяшев, петроглифтер, биікке шығу, экспедиция, шәкірттер, таулар, альпинизм

\section{MEMORY OF THE TEACHER}

\section{A.A. Goryachev}

The article highlights the main life and creative milestones of a famous archeologist - Alexei Nikolaevich Maryashev., who left this world in March 2018. Despite his age and serious illness A.N. Maryashev continued to go on expeditions, climb, make new discoveries in the field of rock art.

Keywords: archaeology, Maryashev A.N., petroglyphs, climbing, expeditions, students, mountains, mountaineering.

\section{About the Author:}

Goryachev Alexander A. Senior Researcher, A.Kh. Margulan Archeology Institute, Almaty, Kazakhstan; aga.2805@mail.ru 